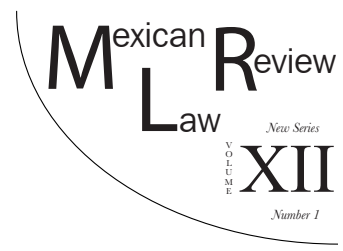

\title{
DONALD TRUMP'S BORDER WALL AND TREATY INFRINGEMENT
}

\author{
Kristi SuTTON* \\ Inan $\mathrm{ULUC}^{* *}$
}

\begin{abstract}
Historically, the relationship between Mexico and the United States was one of respect, understanding, and cooperation. Geographic proximity demands that the two nations exist in harmony and collaborate to maintain a safe border and sustainable water consumption. However, with increasing frequency, the Department of Homeland Security challenges bi-lateral treaties entered into by Mexico and the United States. These treaties continue to face infringement as U.S. Presidents, past and present, build larger, longer southern border walls. This article explores the federal laws supporting this border construction and further discusses the sparse caselaw examining constitutional challenges raised against the Department of Homeland Security regarding the Secretary's waiver authority. Following this exploration, this study probes into the powers of treaty law as strong legal authority used to challenge and prevent future wall construction.
\end{abstract}

Keywords: 1970 Boundary Treaty, 1944 Water Treaty, Executive Order 13767, IIRIRA, REAL ID Act.

RESUMEN: Históricamente la relación entre México y los Estados Unidos ha sido de respeto, entendimiento y cooperación. La cercanía geográfica exige a ambas naciones existir en armonía y colaborar para mantener una frontera segura y un consumo sustentable de agua. Sin embargo, con mayor frecuencia, el Departamento de Seguridad Nacional pone en tela de juicio los tratados bilaterales, firmados por México y Estados Unidos. Estos tratados continúan siendo

* Kristi Rose Sutton is a term law clerk to Chief Bankruptcy Judge Cynthia Norton in Kansas City, Missouri. She is a New York Bar member and former Assistant Professor of Law at the Social Sciences University of Ankara in Turkey. She received her Juris Doctorate degree from Pennsylvania State University, Dickinson School of Law in 2015. Email: krsutton.ks@gmail.com.

** Dr. Inan Uluc is an attorney of the Ankara Bar Association in the Republic of Turkey and an Assistant Professor of Law at the Social Sciences University of Ankara in Turkey. Email: inanuluc@gmail.com. 
Esta revista forma parte del acervo de la Biblioteca Jurídica Virtual del Instituto de Investigaciones Jurídicas de la UNAM http://www.juridicas unam mx/

https://biblio.juridicas.unam.mx/bjv

https://revistas.juridicas.unam.mx/

DOI: http://dx.doi.org/10.22201/iij.24485306e.2019.2.13636

vulnerados en tanto que los presidentes, pasados y presentes de Estados Unidos construyen muros cada vez más grandes y largos. Este artículo explora las leyes federales que apoyan la construcción de muros y analiza la escasa jurisprudencia examinando disputas constitucionales contra el Departamento de Seguridad Nacional con respecto a la facultad de exención del Secretario. Enseguida de esta exploración, este análisis indaga la capacidad del tratado internacional como una fuerte y legal autoridad utilizada para cuestionar y prevenir la futura construcción de muros.

Palabras Glave: Tratado de límites de 1970, Tratado de Aguas de 1944, Órden ejecutiva 13767, Ley de Reforma de Inmigración Ilegal y Responsabilidad del Inmigrante, Ley de Real ID.

\section{TABle of Contents}

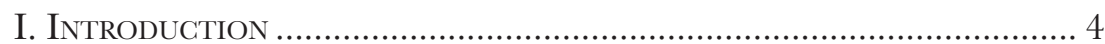

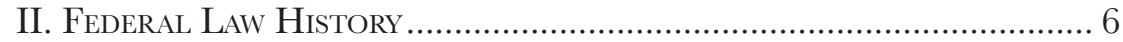

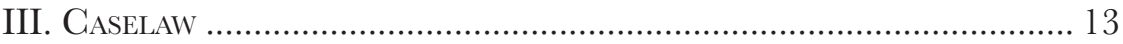

1. Defenders of Wildlife v. Chertoff ............................................. 14

2. Save Our Heritage Organization v. Gonzalez ........................... 16

3. County of El Paso v. Chertoff .................................................. 17

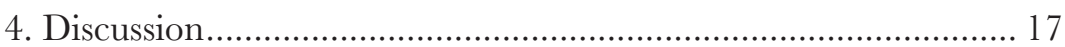

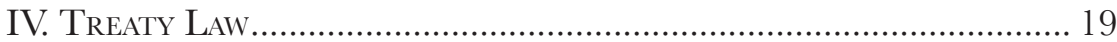

1. U.S. Treaty Authority, its Relationship to Federal Law, and the Power of the Vienna Convention ................................. 19

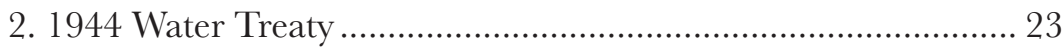

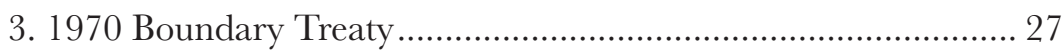

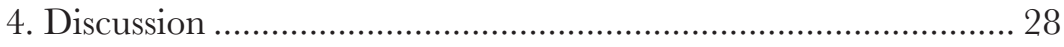

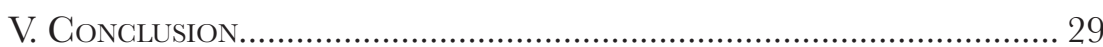

\section{INTRODUCTION}

The accumulation of all powers, legislative, executive, and judiciary, in the same hands, whether of one, a fere, or many, and whether hereditary, self-appointed, or elective, may justly be pronounced the very definition of tyranny.

James Madison

In the wake of September $11^{\text {th }}$, executive strategy sustained a paradigm shift, from unfettered international cooperation and partnership to a robust "my country first" policy. Living in a post-September $11^{\text {th }}$ world, many Ameri- 
cans, regardless of repercussions, demand heightened border security despite that "...the actual existence of a terror threat is, from the perspective of border fortification, only marginally relevant. We- as the citizenry and policymakers - create meaning and ascribe importance to the border through our political and cultural interaction." Consequently, select U.S. leaders, to assuage these fears and anxieties, maintain goals of constructing a more imposing and insurmountable border wall between Mexico and the United States. Notwithstanding that, border fences pose minimal deterrence to illegal immigration, ${ }^{2}$ instigated by the fear of terrorism, the southern border fence has expanded. And today, whether the emotion be fear or something more sinister, this fence faces expansion and fortification under the Trump administration.

Among the most troubling controversies of border construction are the supporting federal laws that provide the Secretary of the Department of Homeland Security with a catbird seat in which the Secretary may waive innumerable laws in the pursuit of border wall construction. This waiver includes the power to dismiss environmental laws and acts such as the Federal Safe Drinking Water Act, the Administrative Procedure Act, ${ }^{3}$ and the Noise Control Act. ${ }^{4}$ Because of this power to effectively ignore laws governing environmental impacts, the border fence is often blamed for "flooding, erosion, rechannelization of water, and the scouring out of the fence foundation itself." 5

Despite constitutional challenges to the federal laws allowing for this expansive waiver, courts maintain that the waiver is constitutional. ${ }^{6}$ While the courts arguably err in their respective reading of the broad scope of this waiver in finding that an intelligible principle exists, the judiciary cannot so easily ignore the law governing treaties and how an extended border wall flagrantly disregards present treaty agreements between Mexico and the United States. Treaty law power finds its foundation under Article VI of the United States

1 Pratheepan Gulasekaran, Symposium Issue: Persistent Puzzles in Immigration Law: Why a Wall?, 2 U.C. Irvine L. Rev. 147, 165-66 (2012) (citing Michiel Baud \& Willem van Schendel, Toward a Comparative History of Borderlands, 8 J. WORLD Hist. 211 , 211 (1997); David Spiro, Criminalizing Immigration: The Social Construction of Borders and National Security, InT'L Stud. Ass'N Working PAPERs, Feb. 20, 2010, at 17).

2 Tiffany N. Tisler, Federal Environmental Law Waivers and Homeland Security: Assessing Waiver Application in Homeland Security Settings at the Southern Border in Comparison to National Security Settings Involving the Military, 42 U. ToL. L. REv. 777, 795 (2011).

3 Jenny Neeley, Over the Line: Homeland Security's Unconstitutional Authority to Waive All Legal Requirements for the Purpose of Building Border Infrastructure, 1(2) ARIZ. J. EnvTL. L. \& POL'y 140, 141 (2011). Note: Administrative Procedure Act is "a law governing the actions of all federal agencies...".

${ }^{4} I d$.

5 Tisler, supra note 2, at 778.

6 See Save Our Heritage Org. v. Gonzalez, 533 F. Supp. 2d 58 (D.D.C. 2008); County of El Paso v. Chertoff, EP-08-CA-196-FM, 2008 U.S. Dist. LEXIS 83045 *1 (W.D. Tex. Aug. 29, 2008); Defenders of Wildlife v. Chertoff, 527 F. Supp. 2d 119 (D.D.C. 2007). 
Constitution, which dictates that treaties are "the supreme law of the land." The United States and Mexico, as indelible friends and allies, entered into multiple bi-lateral treaties, whose terms (i.e. water rights and border agreements) have already been infringed upon and continue to be threatened by the present fence and plans of a future wall. Thus, the future of the border wall rests in the hands of the judiciary. Following an examination of a timeline of amendments to the Illegal Immigration Reform and Immigrant Responsibility Act and then an analysis of the historic judicial deference paid to this Act, this study will show that two specific treaties, namely, the Treaty Relating to Utilization of Waters of the Colorado and Tijuana Rivers and of the Rio Grande Between the United States and Mexico (hereinafter 1944 Water Treaty) and the Treaty to Resolve Pending Boundary Differences and Maintain the Rio Grande and Colorado River as the International Boundary (hereinafter 1970 Boundary Treaty), as self-executing treaties, both of which possess strong legal standing against further border wall construction and, if rightly enforced in court, will provide the strongest legal argument to counter a future border wall founded upon "the broadest waiver in American history."7

\section{Federal Law History}

On August 1, 2017, the Department of Homeland Security (hereinafter DHS), pursuant to Executive Order $13767,{ }^{8}$ announced its intent to waive dozens of laws" "to ensure the expeditious construction of barriers in the

7 Tisler, supra note 2, at 777.

8 Exec. Order No. 13767, Border Security and Immigration Enforcement Improvements, 82 Fed. Reg. 8793 (Jan. 30, 2017).

9 See Determination Pursuant to Section 102 of the Illegal Immigration Reform and Immigrant Responsibility Act of 1996, as amended, 82 Fed. Reg. 35984 (proposed Aug. 2, 2017) available at https://www:federalregister.gov/documents/2017/08/02/2017-16260/determination-pursuant-to-section-102-of-the-illegal-immigration-reform-and-immigrant-responsibility, see also Determination Pursuant to Section 102 of the Illegal Immigration Reform and Immigrant Responsibility Act of 1996, as amended, 82 Fed. Reg. 42829 (proposed Sept. 12, 2017), available at https://wrwre. federalregister.gov/documents/2017/09/12/2017-19234/determination-pursuant-to-section-102-of-theillegal-immigration-reform-and-immigrant-responsibility.

The following represents the laws waived pursuant to Section 102 waiver authority:

The National Environmental Policy Act (Pub. L. 91-190, 83 Stat. 852 (Jan. 1, 1970) (42 U.S.C. 4321 et seq.)), the Endangered Species Act (Pub. L. 93-205, 87 Stat. 884 (Dec. 28, 1973) (16 U.S.C. 1531 et seq.)), the Federal Water Pollution Control Act (commonly referred to as the Clean Water Act (33 U.S.C. 1251 et seq.)), the National Historic Preservation Act (Pub. L. 89665, 80 Stat. 915 (Oct. 15, 1966), as amended, repealed, or replaced by Pub. L. 113-287 (Dec. 19, 2014) (formerly codified at 16 U.S.C. 470 et seq., now codified at 54 U.S.C. 100101 note and 54 U.S.C. 300101 et seq.)), the Migratory Bird Treaty Act (16 U.S.C. 703 et seq.), the Migratory Bird Conservation Act (16 U.S.C. 715 et seq.), the Clean Air Act (42 U.S.C. 7401 et seq.), the Archeological Resources Protection Act (Pub. L. 96-95 (16 U.S.C. 470aa et seq.)), the Paleonto- 
Esta revista forma parte del acervo de la Biblioteca Jurídica Virtual del Instituto de Investigaciones Jurídicas de la UNAM http://www.juridicas.unam.mx/ https://biblio.juridicas.unam.mx/bjv https://revistas.juridicas.unam.mx/

vicinity of the international border near Calexico, California." ${ }^{10}$ Manifest in this list is the expansive power bestowed upon the DHS in the "federal initiative to 'secure the southern border of the United States through immediate construction of a physical wall on the southern border,' covering roughly 2000 miles." 11 The following section explores where this unprecedented legal power originated and cultivated.

Nearly twenty years prior to September $11^{\text {th }}$, concerns of drug smuggling instigated the federal government of the United States to "beg[i]n building walls for the purpose of separating people...starting with a single fence at the border south of San Diego." "12 This concern instigated President Clinton to sign the "Illegal Immigration Reform and Immigrant Responsibility Act of 1996"

logical Resources Preservation Act (16 U.S.C. 470aaa et seq.), the Federal Cave Resources Protection Act of 1988 (16 U.S.C. 4301 et seq.), the National Trails System Act (16 U.S.C. 1241 et seq.), the Safe Drinking Water Act (42 U.S.G. $300 f$ et seq.), the Noise Control Act (42 U.S.C. 4901 et seq.), the Solid Waste Disposal Act, as amended by the Resource Conservation and Recovery Act (42 U.S.C. 6901 et seq.), the Comprehensive Environmental Response, Compensation, and Liability Act (42 U.S.C. 9601 et seq.), the Archaeological and Historic Preservation Act (Pub. L. 86-523, as amended, repealed, or replaced by Pub. L. 113-287 (Dec. 19, 2014) (formerly codified at 16 U.S.C. 469 et seq., now codified at 54 U.S.C. 312502 et seq.)), the Antiquities Act (formerly codified at 16 U.S.C. 431 et seq., now codified 54 U.S.C. 320301 et seq.), the Historic Sites, Buildings, and Antiquities Act (formerly codified at 16 U.S.C. 461 et seq., now codified at 54 U.S.C. 3201-320303 \& 320101-320106), the Wild and Scenic Rivers Act (Pub. L. 90-542 (16 U.S.C. 1281 et seq.)), the Farmland Protection Policy Act (7 U.S.C. 4201 et seq.), the Coastal Zone Management Act (Pub. L. 92-583 (16 U.S.C. 1451 et seq.)), the Wilderness Act (Pub. L. 88-577 (16 U.S.C. 1131 et seq.)), the Federal Land Policy and Management Act (Pub. L. 94-579 (43 U.S.C. 1701 et seq.)), the National Wildlife Refuge System Administration Act (Pub. L. 89669 (16 U.S.C. 668dd-668ee)), the National Wildlife Refuge System Improvement Act of 1997 (Pub. L. 105-57), National Fish and Wildlife Act of 1956 (Pub. L. 84-1024 (16 U.S.C. 742a, et seq.)), the Fish and Wildlife Coordination Act (Pub. L. 73-121 (16 U.S.C. 661 et seq.)), the Wild Horse and Burro Act (16 U.S.C. 1331 et seq.), an Act of Oct. 30, 2000, Pub. L. 106-398, 1, 114 Stat. 1654 (enacting into law $\S 2848$ of Part II of Subtitle D of Title XXVIII of Division B of H.R. 5408 (114 Stat. 1654A-426), as introduced on Oct. 6, 2000), the Administrative Procedure Act (5 U.S.C. 551 et seq.), the Otay Mountain Wilderness Act of 1999 (Pub. L. 106-145), sections 102(29) and 103 of Title I of the California Desert Protection Act (Pub. L. 103-433), the Rivers and Harbors Act of 1899 (33 U.S.C. 403), the Eagle Protection Act (16 U.S.C. 668 et seq.), the Native American Graves Protection and Repatriation Act (25 U.S.C. 3001 et seq.), the American Indian Religious Freedom Act (42 U.S.C. 1996), and the Religious Freedom Restoration Act (42 U.S.C. 2000bb).

10 See supra note 9. Determination Pursuant to Section 102 of the Illegal Immigration Reform and Immigrant Responsibility Act of 1996, as amended, 82 Fed. Reg. 42829 (proposed Sept. 12, 2017).

11 Marshal Garbus, Comment: Environmental Impact of Border Security Infrastructure: How Department of Homeland Security's Waiver of Environmental Regulations Threatens Environmental Interests Along the U.S.-Mexico Border, 31 Tul. EnvTL. L.J. 327, 328 (2018) (citing Exec. Order No. 13767, Border Security and Immigration Enforcement Improvements, 82 Fed. Reg. 8793 (Jan. 30, 2017)).

12 Dinah Bear, Esq., Border Wall: Broadest Waiver of Law in American History, CENTER FOR ENv. Law, 1 (2009), available at http://wrerreciel.org/Publications/BorderWall_8Feb09.pdf. 
(hereinafter IIRIRA). ${ }^{13}$ Relevantly, the original language of the 1996 IIRIRA, relating to today's proposed border wall includes:

Sec. 102. Improvement of Barriers at Border.

(a) In General.- The Attorney General, in consultation with the Commissioner of Immigration and Naturalization, shall take such actions as may be necessary to install additional physical barriers and roads (including the removal of obstacles to detection of illegal entrants) in the vicinity of the United States border to deter illegal crossings in areas of high illegal entry into the United States.

(b) Construction of Fencing and Road Improvements in the Border Area Near San Diego, Galifornia.-

(1) In General.- - In carrying out subsection (a), the Attorney General shall provide for the construction along the 14 miles of the international land border of the United States, starting at the Pacific Ocean and extending eastward, of second and third fences, in addition to the existing reinforced fence, and for roads between the fences.

(2) Prompt Acquisition of Necessary Easements.-The Attorney General, acting under the authority conferred in section 103(b) of the Immigration and Nationality Act (as inserted by subsection (d)), shall promptly acquire such easements as may be necessary to carry out this subsection and shall commence construction of fences immediately following such acquisition (or conclusion of portions thereof). 8 USG 1103 note. 110 STAT. 3009-555 Public LaW 104-208-SePt. 30, 1996.

(3) Safety Features. - The Attorney General, while constructing the additional fencing under this subsection, shall incorporate such safety features into the design of the fence system as are necessary to ensure the well-being of border patrol agents deployed within or in near proximity to the system.

(4) Authorization Of Appropriations. - There are authorized to be appropriated to carry out this subsection not to exceed $\$ 12,000,000$. Amounts appropriated under this paragraph are authorized to remain available until expended.

(c) WAIVER. - The provisions of the Endangered Species Act of 1973 and the National Environmental Policy Act of 1969 are waived to the extent the Attorney General determines necessary to ensure expeditious construction of the barriers and roads under this section. ${ }^{14}$

This Act expressly ordered the construction of barriers along the border to prevent illegal immigration ${ }^{15}$ and while President Clinton hesitated over

13 Id. at 2.

14 Illegal Immigration Reform and Immigrant Responsibility Act of 1996 (IIRIRA), Pub. L. No. 104-208, 110 Stat. 3009 (codified as amended in scattered sections of 8 U.S.C. and 18 U.S.G.) (emphasis added).

15 Michael John Garcia, Cong. Research Serv., R43975, Barriers Along the U.S. Borders: Key Authorities and Requirements 5 (Jan. 27, 2017). 
the express "waive[r] 'to the extent...necessary to ensure expeditious construction of the barriers and roads under this section' [of] provisions of the Endangered Species Act and the National Environmental Policy Act," he felt certain that the Attorney General shared his parallel commitment to environmental protection. ${ }^{16}$ President Clinton based his confidence that environmental laws would be respected upon the Immigration Naturalization Service's memo stating its intent not to utilize the Attorney General's waiver and to abide by environment-friendly policies. ${ }^{17}$ Clinton similarly felt assured by the limited language of the Act prescribing the specific location of the fence and expressly dictating any waivable laws. Following initial controversy and dissent by the American collective, as time passed, public voice seemingly lost interest in this controversial waiver. However, in California, where the border wall was to be constructed, local antagonism continued and eventually stalled the project. ${ }^{18}$

Following the arrest of the building campaign, public attention paid to President Clinton's environmental law waiver quieted for the next several years. However, successive to September $11^{\text {th }}$ and the passage of the Homeland Security Act of 2002, the government's strategy to augment national security led to the transference of border security control to the DHS (effectively dismantling the Immigration and Naturalization Service). ${ }^{19}$ Subsequently, in furtherance of the administration's goals to suppress terrorist threats, in 2005, the IIRIRA waiver authority

was expanded by the REAL ID Act to encompass not just the San Diego fence, but all barriers and roads that may be constructed pursuant to IIRI[R] A. It was also expanded to apply not just to NEPA and the ESA, but to 'all legal requirements [the DHS] Secretary, in such Secretary's sole discretion, determines necessary to ensure expeditious construction of the barriers and roads[.] ${ }^{, 20}$

Notably, while the REAL ID Act sought to quiet concern regarding illegal immigration from Latin America, ${ }^{21}$ the act also passed under the color of September 11, 2001. The irony of this amendment is that the terrorists responsible for the September $11^{\text {th }}$ tragedy "entered the United States through legal ports of entry," and therefore, the reasoning, at least in part, that sup-

16 Bear, supra note 12 , at 2.

17 Id. at 3.

$18 I d$.

$19 I d$.

20 Neeley, supra note 3, at 144.

21 David Fisher, The U.S. - Mexico Border Wall and the Case for "Environmental Rights", 50 TEx. INT'L L.J. 145, 146 (2015). 
ported this expansion of power did not correlate to the purported problem. ${ }^{22}$ In fact, according to Assistant Professor Gulasekaran,

[p]rior to $9 / 11$, the creation of walls and fences was not popular amongst lawmakers, and other than a cosmetic fourteen-mile fence, the border was not physically fortified. The events of 9/11 drastically altered the immigration debate, and inexplicably focused attention on the southern border of the United States as a potential entry point for terrorist threats. The empirical dubiousness of the terrorism/immigration association aside, the focus of the southern border meant that migrants from Mexico and Central America would be constructed in the American imagination as threats to the nation's rule-of-law ideals, its economic security, and its national security. ${ }^{23}$

Clear from Assistant Professor Gulasekaran, the notion that a secured southern border wall will prevent further tragedies like September $11^{\text {th }}$ is nothing more than a social construction by policymakers to manipulate the American public into focusing their fears on a specific thing and group of people. Further troubling is that this sweeping authority, camouflaged as an "amendment attached to must-pass appropriation measures funding the Iraq war and Indonesian tsunami relief... was passed without any consideration by the appropriate committees." ${ }^{24}$ Unfortunately, by passing such an expansive law as an amendment, it is probable that this legislation failed to receive the proper attention and debate it was due.

Succeeding this amendment, the IIRIRA faced amendment and expansion twice more: once in 2006, with the passage of the Secure Fence Act and again in 2008 with the Consolidated Appropriations Act. The impact of these three amendments on the IIRIRA was extensive and is evident in the language of the IIRIRA in its present form:

(a) In General.- The Secretary of Homeland Security shall take such actions as may be necessary to install additional physical barriers and roads (including the removal of obstacles to detection of illegal entrants) in the vicinity of the United States border to deter illegal crossings in areas of high illegal entry into the United States.

(b) Construction of Fencing and Road Improvements Along the Border.-

(1) Additional fencing along southwest border.-

22 Tisler, supra note 2, at 795.

23 Gulasekaran, supra note 1, at 163-64.

24 Neeley, supra note 3, at 144 (citing Tana Sanchez, Waiving Good-bye to Environmental Lawes Along the Arizona Borderlands, 16 Mo. Envtl. L \& Pol'y Rev. 281, 289 (2009); Andrea C. Sancho, Note, Environmental Concerns Created by Current U.S. Border Policy: Challenging the Extreme Waiver Authority Granted to the Secretary of the Department of Homeland Security under the REAL ID Act of 2005, 16 S.E. ENVTL. L.J. 421, 426 (2008)). 
(A) Reinforced fencing.- In carrying out subsection (a), the Secretary of Homeland Security shall construct reinforced fencing along not less than 700 miles of the southwest border where fencing would be most practical and effective and provide for the installation of additional physical barriers, roads, lighting, cameras, and sensors to gain operational control of the southwest border.

(B) Priority areas.- In carrying out this section [amending this section], the Secretary of Homeland Security shall-

(i) identify the 370 miles, or other mileage determined by the Secretary, whose authority to determine other mileage shall expire on December 31, 2008, along the southwest border where fencing would be most practical and effective in deterring smugglers and aliens attempting to gain illegal entry into the United States; and

(ii) not later than December 31, 2008, complete construction of reinforced fencing along the miles identified under clause (i).

(C) Consultation.-

(i) In general.- In carrying out this section, the Secretary of Homeland Security shall consult with the Secretary of the Interior, the Secretary of Agriculture, States, local governments, Indian tribes, ${ }^{25}$ and property owners in the United States to minimize the impact on the environment, culture, commerce, and quality of life for the communities and residents located near the sites at which such fencing is to be constructed.

(ii) Savings provision. - Nothing in this subparagraph may be construed to-

(I) create or negate any right of action for a State, local government, or other person or entity affected by this subsection; or

(II) affect the eminent domain laws of the United States or of any State.

(D) Limitation on requirements. - Notwithstanding subparagraph (A), nothing in this paragraph shall require the Secretary of Homeland Security to install fencing, physical barriers, roads, lighting, cameras, and sensors in a particular location along an international border of the United States, if the Secretary determines that the use or placement of such resources is not the most appropriate means to achieve and maintain operational control over the international border at such location.

(2) Prompt acquisition of necessary easements.-The Attorney General, acting under the authority conferred in section 103(b) of the Immigration and Nationality Act [8 U.S.C. 1103(b)] (as inserted by subsection (d)), shall promptly acquire such easements as may be necessary to carry out this subsection and shall commence construction of fences immediately following such acquisition (or conclusion of portions thereof).

(3) Safety features.-The Attorney General, while constructing the additional fencing under this subsection, shall incorporate such safety features into the design of the fence system as are necessary to ensure the well-being of border patrol agents deployed within or in near proximity to the system.

25 But see, supra note 9, discussing DHS' recent Waiver of laws including those pertaining to Indian Tribes (e.g. the Native American Graves Protection and Repatriation Act (25 U.S.C. 3001 et seq.), the American Indian Religious Freedom Act (42 U.S.C. 1996), and the Religious Freedom Restoration Act (42 U.S.C. 2000bb). 
(4) Authorization of appropriations. - There are authorized to be appropriated such sums as may be necessary to carry out this subsection. Amounts appropriated under this paragraph are authorized to remain available until expended.

(c) Waiver.-

(1) In general.- Notwithstanding any other provision of law, the Secretary of Homeland Security shall have the authority to waive all legal requirements such Secretary, in such Secretary's sole discretion, determines necessary to ensure expeditious construction of the barriers and roads under this section [amending this section]. Any such decision by the Secretary shall be effective upon being published in the Federal Register.

(2) Federal court review.-

(A) In general.- The district courts of the United States shall have exclusive jurisdiction to hear all causes or claims arising from any action undertaken, or any decision made, by the Secretary of Homeland Security pursuant to paragraph (1). A cause of action or claim may only be brought alleging a violation of the Constitution of the United States. The court shall not have jurisdiction to hear any claim not specified in this subparagraph.

(B) Time for filing of complaint.-Any cause or claim brought pursuant to subparagraph $(\mathrm{A})$ shall be filed not later than 60 days after the date of the action or decision made by the Secretary of Homeland Security. A claim shall be barred unless it is filed within the time specified.

(C) Ability to seek appellate review.-An interlocutory or final judgment, decree, or order of the district court may be reviewed only upon petition for a writ of certiorari to the Supreme Court of the United States. ${ }^{26}$

The power and authority of this act cannot be understated. First, in Section 102(a), the Secretary "shall take such actions as may be necessary" to assure that a border wall is constructed, to deter illegal immigrants in the "vicinity of the United States." The Secretary, therefore, has the "discretion to determine the appropriate amount of 'additional' barriers to deploy, as well as the most appropriate locations to install such barriers...." 27 This is clearly a greater delegation of power than any previously given to the Attorney General under the 1996 IIRIRA, as the Act then required consultation with the Commissioner of Immigration and Naturalization when making border decisions. ${ }^{28}$ Next, Section 102(b), originally limiting the border wall to the San Diego area, now permits a border wall at least 700 miles long and in the areas

268 U.S.C., 2016 Edition Title 8 - Aliens and Nationality Chapter 12 - Immigration and Nationality Subchapter I - General Parovisions Sec. 1103 - Powers and duties of the Secretary, the Under Secretary, and the Attorney General Pub. L. 104-208, div. C, title I, $\S 102$ (a)-(c), Sept. 30, 1996, 110 Stat. 3009-554, 3009-555, as amended by Pub. L. 109-13, div. B, title I, §102, May 11, 2005, 119 Stat. 306; Pub. L. 109-367, §3, Oct. 26, 2006, 120 Stat. 2638; Pub. L. 110-161, div. E, title V, §564(a), Dec. 26, 2007, 121 Stat. 2090 (emphasis added).

27 Garcia, supra note 15 , at 5.

28 See supra note 13, § 102(a). 
Esta revista forma parte del acervo de la Biblioteca Jurídica Virtual del Instituto de Investigaciones Jurídicas de la UNAM

dictated solely by the Secretary. ${ }^{29}$ Also notable in Section 102(b) is the apparent freedom the Secretary enjoys when choosing both fence type and height when building the wall. ${ }^{30}$ The repercussions of this autonomy, when coupled with the ability to waive an indeterminable number of laws, are an unsettling scenario without any clear balance of power. Third, relating to the balance of power, Section 102(c) now limits judicial review of waiver decisions of solely constitutional claims to only District Courts and appellate review is singly available in the Supreme Court of the United States. "The removal of access to justice by removing the ability to challenge the DHS waivers except on constitutional grounds removes a critical tool in efforts to hold agencies accountable." 31 This limitation on judicial review is arguably the most controversial aspect of this Act and is ripe for constitutional criticism.

In sum, the evolution of the 1996 IIRIRA through the 2005, 2006, and 2008 amendments, evidences a trend veering away from concern of environmental laws and citizens' rights, towards the greater interest of securing a border wall. Notwithstanding the copious power reserved to the Secretary regarding border wall construction, the following section illustrates the judicial deference courts show in support of this congressional delegation of power.

\section{Gaselaw}

Caselaw confronting the expansive power under the IIRIRA is both startling and dispiriting. This discussion looks at 1) Defenders of Wildlife, 2) Save Our Heritage Organization, and 3) County of El Paso. ${ }^{32}$ These cases reflect how District Courts tackle the constitutionality of the Secretary's waiver authority under Section 102. Following an examination into how the courts tackled these cases, this study explores the errors in the analyses these holdings propound.

Following the expansion of the 1996 IIRIRA, the courts began to encounter petitions founded upon constitutional claims rallied against the Secretary's waivers. Notably, the number of these cases is few, as the amended IIRIRA made bringing claims exceedingly difficult.

29 GARCIA, supra note 15 , at 10.

30 Id. at 13-14. See also Annecoos Wiersema, Unseen Harms: The U.S.-Mexico Border Wall and Its Lessons for Wildlife and Biodiversity Advocates, 95 Denv. L. Rev. Online 88, 93 (2018) ("The IIRIRA's removal of required formal consultation and environmental impact assessment significantly limits the ability of scientists and policy makers to ensure that border wall construction will not harm wildlife.")

31 Wiersema, supra note 30, at 93.

32 Save Our Heritage Org. v. Gonzalez, 533 F. Supp. 2d 58 (D.D.C. 2008); County of El Paso v. Chertoff, EP-08-CA-196-FM, 2008 U.S. Dist. LEXIS 83045 *1 (W.D. Tex. Aug. 29, 2008); Defenders of Wildlife v. Chertoff, 527 F. Supp. 2d 119 (D.D.C. 2007). 
Esta revista forma parte del acervo de la Biblioteca Jurídica Virtual del Instituto de Investigaciones Jurídicas de la UNAM

\section{Defenders of Wildlife v. Chertoff}

The primary case evincing rebellion against the powers bestowed upon the Secretary of the DHS under the IIRIRA is Defenders of Wildlife v. Chertoff.33 In Defenders, the plaintiffs challenged the constitutionality of the Secretary's waiver of federal laws, as permitted under Section 102 of the REAL ID Act. ${ }^{34}$ Here, the plaintiffs initially alleged that the wall construction infringed upon "'a unique and invaluable environmental resource' and 'one of the most biologically diverse areas of the United States." "35 Due to the possible irreparable harm that a fence could cause, the plaintiffs sought and received emergency injunctive relief to delay construction of the fence. ${ }^{36}$ However, approximately two weeks following the court's injunctive relief, Secretary Chertoff "published a notice in the Federal Register waiving NEPA, the Arizona-Idaho Conservation Act, and eighteen other laws with respect to the construction of the...fence under the authority granted to him by Section 102 of the REAL ID Act of 2005."37 Subsequent to the Secretary's waiver, the plaintiffs amended their complaint to argue that the waiver authority of the REAL ID Act violated Articles I and II of the Constitution "because it impermissibly delegates legislative powers to the DHS Secretary, a politically-appointed Executive Branch official." 38

Consequently, the sole issue the court tackled was "whether the Secretary's waiver under the REAL ID Act [was] constitutional." 39 Here, the plaintiffs, in reliance upon Clinton v. City of $\mathcal{N}_{\text {ew }}$ Kork, ${ }^{40}$ argued that the waiver provision "provides the DHS Secretary with roving commission to repeal, in his sole discretion, any law in all 50 titles of the United States Code that he concludes might impede construction of a border wall." 41 The Court, in Clinton, "struck down the Line Item Veto Act of 1996... because the Court found that the Act - '[i]n both legal [and] practical effect'- allowed the President to amend Acts of Congress by repealing portions of them." 42 The plaintiffs in Defenders paralleled Clinton to their case because "[t] he power granted by Section 102 of the REAL ID Act to the Secretary of DHS to 'waive' the applicability of any law that would otherwise apply to border wall and fence construction projects is

33 Defenders of Wildlife, 527 F. Supp. 2d at 119.

34 Id. at 120-21.

35 Id. at 121 (citing Pls.' Mem. In Sup. of Mot. for Temporary Restraining Order [“TRO

Mo."] at 1, 4-5).

36 Id. at 121 .

37 Id. at 121-22.

38 Id. at 123 (citing Am. Compl. Paras. 36-38).

39 Id. at 123.

40 Clinton v. City of New York, 524 U.S. 417 (1998).

41 Defenders of Wildlife, 527 F. Supp. 2d at 123 (citing Pls.' Opp'n at 3-4 (emphasis omitted)).

42 Id. (citing Clinton, 524 U.S. at 438). 
unmistakably the power partially to repeal or amend such laws." 43 This power, the plaintiffs argued, was therefore an "impermissible exercise of legislative authority." 44

While the plaintiffs' argument was strong, the Defenders court summarily dismissed the parallel to the Clinton line item veto case. The court stated that the REAL ID Act's waiver differed from the Clinton case because here, the "Secretary has no authority to alter the text of any statute, repeal any law, or cancel any statutory provision, in whole or in part." 45 Further, the court rejected the general argument propounded by the plaintiffs that the waiver authority violated the separation of powers principle because the court found that Congress acted well-within its duties to delegate its legislative power with sufficient guidance and that this guidance was made clear with the language of "necessary to ensure expeditious construction of the barriers and roads under [Section 102 of IIRIRA]." "Finally, the court refused to entertain the plaintiffs' last argument proposing that this waiver was unprecedented and too broad in effect:

[ $\mathrm{t}$ he Court concludes that it lacks the power to invalidate the waiver provision merely because of the unlimited number of statutes that could potentially be encompassed by the Secretary's exercise of his waiver power. Rather, under the nondelegation doctrine, the relevant inquiry is whether the Legislative Branch has laid down an intelligible principle to guide the Executive Branch, not the scope of the waiver power. Therefore, based on controlling Supreme Court precedent, the Court finds that the REAL ID Act's waiver provision is a valid delegation of authority. ${ }^{47}$

Here, the court noted the deference judges usually bestow to both the executive and legislative branches when the subject matter involves foreign affairs, immigration control, and border concerns: "the [e]xecutive has 'a degree of discretion and freedom from statutory restriction which would not be admissible were domestic affairs alone involved." 48 Further,

when Congress legislates on foreign affairs or immigration control, "it is not dealing alone with a legislative power. It is implementing an inherent executive power.... [b] ecause these powers are 'also inherent in the executive department of the sovereign, Congress may in broad terms authorize the executive to exercise [them]. . ." 49 This purported deference to the other

43 Id. (citing Pls. Opp'n at 9-10 (internal quotes omitted)).

44 Id. (citing Pls. Surreply at 1, 2).

45 Id. at 123.

46 Id. 126-27 (citing 8 U.S.C. section 1103 note).

47 Id. at 129 .

48 Id. (citing Clinton, 524 U.S. at 445 (quoting Curtiss-Wright Export Corp., 299 U.S. at 320, 57

S.Ct. 216)) (internal quotations omitted).

49 Id. (citing Knauff v. Shaughnessy, 338 U.S. 537, 542-43 (1950)). 
government branches was the 'nail in the coffin' for the petitioners' argument and the District Court resolved the case by dismissing it with prejudice. ${ }^{50}$ Finally, as the IIRIRA limits appellate jurisdiction to the Supreme Court, petitioners had one final chance and filed a Petition for Certiorari. However, the Court denied the petition and the case remained 'dead in the water.'

\section{Save Our Heritage Organization v. Gonzalez}

The next case to challenge the constitutional delegation of power to DHS Secretary Chertoff, was Save Our Heritage Org. ${ }^{51}$ Here, petitioners, citing two separate barriers, one in San Diego, California and the other, near Yuma, Arizona, argued that the "Government neglected to comply with several statutes and that DHS Secretary Michael Chertoff's waiver of those statutory requirements [was] unconstitutional." "52 The District Court, in tackling the constitutionality of Congress' delegation of authority, noted that the court must look to whether the "statute in question sets forth an intelligible principle to which the person or body authorized to [exercise the delegated authority] is directed to conform." Noting the broad power Congress has in this delegation and the usual judicial deference bestowed upon this delegation, the court added that "a statute need only 'clearly delineate[ the general policy, the public agency which is to apply it, and the boundaries of this delegated authority." 54

The District Court harkened back to Defenders of Wildlife in finding the waiver power constitutional. ${ }^{55}$ In Defenders, the judge not only found the directive of "installing additional barriers and roads" (general policy) to be "clearly delineated," but also that the "boundaries" were clearly defined "by Congress' requirement that the Secretary may waive only those laws that he determines "necessary to ensure expeditious construction." 56 This court found Defenders persuasive and noted the significant authority of the executive branch in the area of foreign affairs and immigration even before Congress made this legislative delegation and held the barriers in San Diego and Yuma to be well within this "independent constitutional authority." 57 In sum, the court, persuaded by Defenders, found the waiver power to be constitutional. ${ }^{58}$

\footnotetext{
50 Id.

51 Save Our Heritage Org. v. Gonzalez, 533 F. Supp. 2d 58 (D.D.C. 2008).

$52 I d$. at 60 (citations omitted).

53 Id. at 62 (internal quotations and citations omitted).

54 Id. (internal quotations and citations omitted).

55 Id. at 63.

56 Id. (citing IIRIRA $\S 102)$.

$57 I d$. at 63 (citations omitted).

58 Id. at 64.
} 


\section{County of El Paso v. Chertoff}

Third and last, the holding of County of El Paso ${ }^{59}$ suffered a similar fate to Defenders and Save Our Heritage. In County of El Paso, the plaintiffs challenged two waivers under the REAL ID Act following two waivers by Secretary Chertoff, nulling dozens of federal laws covering over 500 miles of the U.S. border with Mexico. ${ }^{60}$ The plaintiffs argued three specific constitutional issues against the "Waiver Legislation: (1) a nondelegation challenge pursuant to Article I, Section I, of the Constitution, (2) a Presentment Clause challenge pursuant to Article I, Section 7, of the Constitution, and (3) a federalism challenge pursuant to the Constitution's Tenth Amendment."61 The District Court unsurprisingly rejected all three arguments: (1) regarding the nondelegation challenge, the court stated that Congress properly delegated its authority and provided the Secretary with an intelligible principle that directed his waivers for the purpose of expeditious "construction of physical barriers and roads of the nation's borders;" 62 (2) concerning the Presentment Clause, the court found no violations because, unlike the relevant laws in Clinton's line item veto in Clinton v. New York, here, the laws waived under Section 102 still applied outside the Secretary's waiver; ${ }^{63}$ and finally, (3) relating to a violation of the Tenth Amendment, the District Court found no issue because of Section 102's clear intent to preempt state and local laws "which would interfere with Congress's objective to expeditiously construct [a] border fence.",64 Thus, the court found the actions of Secretary Chertoff to be constitutionally sound and further, that the Congressional delegation survived constitutional challenge. Following this case, the plaintiffs petitioned the Supreme Court for review, but again, the Court declined the petition. ${ }^{65}$

\section{Discussion}

Clearly, the judiciary defers to Congress' delegation authority, particularly in matters concerning foreign affairs and immigration. Well recognized is the idea that "Congress would be guilty of delegating the legislative power only if it gave something approaching blank-check legislative rulemaking author-

59 County of El Paso v. Chertoff, EP-08-CA-196-FM, 2008 U.S. Dist. LEXIS $83045 * 1$ (W.D. Tex. Aug. 29, 2008).

60 Kate R. Bowers, Saying What the Law Isn't: Legislative Delegations of Waiver Authority in Environmental Laws, 34 HaRv. EnvTl L. Rev. 257, 282 (2010) (citation omitted).

61 Petition for a Writ of Certiorari at Appendix 53a, County of El Paso v. Napolitano, No. $08-751$.

\footnotetext{
62 Id. (citations omitted).

63 Id. at 54a (citations omitted).

64 Id. (citations omitted).

65 Bowers, supra note 60, at 283.
} 
ity to an agency. As long as an agency's discretion is somewhat confined... then there has been no delegation of 'legislative power." "66 This deference walks a fine line between constitutional and unconstitutional delegation of power. To illustrate, Defenders established strong precedent when it tackled the constitutionality of the waiver power. However, this note argues that the court erred when it did not find the petitioners' comparison with Clinton's line item veto to be relevant. The court dismissed the Presentment Clause argument because the waiver did not equate to a partial repeal. ${ }^{67}$ Notwithstanding the court's findings, the Secretary's actions, in effect, void any law, without limit, and bypass all constitutional "requirements for enacting and repealing laws." $" 68$ On its face, this delegation violates the Constitution. Further, this waiver, while it supposedly has an intelligible principle, the phrase "necessary to ensure expeditious construction of the barriers and roads..." in Section 102 is hardly intelligible and allows the Secretary, in his or her sole capacity as an appointed-executive official, to waive infinite laws, any time and for any perceived obstruction. This power is a far cry from the original intent of the 1996 IIRIRA that specifically expressed the area where the border fence was to be constructed and what laws could be waived in this specific pursuit. Neeley, a licensed attorney and conservation policy director for Sky Island Alliance, astutely notes that while the Defenders opinion ignores the unprecedented scope of the waiver and argues it had no legal right to strike this delegation of authority, this was (and is) precisely the kind of delegation that a court may strike. ${ }^{69}$

In addition to this broad waiver, limits on judicial review are arguably contrary to the nondelegation doctrine as they interfere with impartial review and thus it remains "impossible in a proper proceeding to ascertain whether the will of Congress has been obeyed." ${ }^{, 70}$ Because Section 102(c) limits petitions to constitutional challenges in District Court, the number of possible claims is severely limited to aggrieved parties. Further, appellate constraint challenges the constitutionality of Section 102 because the Supreme Court has discretion to hear a case and has, thus far, rejected cases challenging waiver authority, leaving parties effectively without appellate recourse. In sum, this caselaw discussion evidences the troubling trend in judicial deference regarding the REAL ID Act's expansive delegation of power to the DHS Secretary. Consequently, to successfully prevent further southern border wall construction, a different legal track must be employed. This legal track finds its place

66 Thomas W. Merrill, Rethinking Article 1, Section 1: From Nondelegation to Exclusive Delegation, 104 Colum. L. Rev. 2097, 2099 (2004).

67 Neeley, supra note 3, at 151.

68 Id. at 150.

$69 I d$. at 156.

70 Id. at 158 (citations omitted). 
under Article VI of the Constitution regarding treaties and their authority as "supreme law of the land."

\section{TREATY LAW}

Clear thus far, under both federal law and caselaw, the DHS Secretary has expansive authority over the construction of the southern border wall. However, largely ignored in the discussion of the legality of President Trump's proposed border wall construction is treaty law. Presently, there are treaties governing boundary and water passage between the United States and Mexico that currently face infringement from unilateral border construction. The following sections delve into the history of treaties, their respective influence in the United States, and glimpses into the 1944 Water Treaty and the 1970 Boundary Treaty to conclude that notwithstanding the great power bestowed upon the Secretary under Section 102 of the amended IIRIRA, treaty law demands that the DHS must, at a bare minimum, consult with Mexico prior to any significant border wall construction.

\section{U.S. Treaty Authority, its Relationship to Federal Law, and the Power of the Vienna Convention}

From the founding of the United States, international treaties have shaped the laws of the country. To illustrate, following the American Revolution, the United States entered into the 1783 Treaty of Peace with Great Britain. ${ }^{71}$ Unfortunately, this treaty faced much difficulty as the states refused to honor the obligations outlined and in fact, abjectly opposed the terms. ${ }^{72}$ However, the following language, dictated in the Supremacy Clause of Article VI, Clause 2 of the United States Constitution, made treaties supreme over state law, required judges to enforce a treaty's terms, and effectively remedied state-led obstruction: ${ }^{73}$

[ $\mathrm{t}$ ] his Constitution, and the laws of the United States which shall be made in pursuance thereof; and all treaties made, or which shall be made, under the authority of the United States, shall be the supreme law of the land; and the judges in every state shall be bound thereby, anything in the Constitution or laws of any State to the contrary notwithstanding.

71 Leonie W. Huang, Which Treaties Reign Supreme? The Dormant Supremacy Clause Effect of Implemented Non-Self-Executing Treaties, 79 FordHAm L. Rev. 2210, 2217 (2011).

72 Id. at 2218.

73 Id. at 2219. 
Notably absent from this language is an express clarification of which U.S. law, federal or treaty, reigns supreme. However, the Supreme Court explained, "[b] ecause they enjoy the same constitutional dignity as statutes, treaties will even displace earlier inconsistent federal statutes, although the reverse is also true under the "later-in-time-rule." 74 This authority is critical when balancing the power between federal statutes and treaties because it evidences the strength of treaty law. Applicable to this discussion, the original IIRIRA established in 1996 obviously came after the 1944 and 1970 treaties. However, as originally dictated, the terms between the IIRIRA and the treaties were not overtly inconsistent (although, it may be argued that, even then, the San Diego wall influenced the rights of Mexico under the treaties).

Conversely, today, because the amended IIRIRA gives unfettered control to the DHS Secretary and because, to date, the Secretary used this power to waive countless laws without regard to current treaties, there is undoubtedly a conflict between the treaties' terms and the federal law. Harkening to the Supreme Court's words weighing the authority of inconsistent language between an older law and new legislation, it may still be argued that the intent behind the IIRIRA, as originally drafted and amended, was not to supersede the treaties. Because breaking treaties is not often advisable absent material breach or extenuating circumstances and because Mexico and the United States have a longstanding symbiotic relationship, it cannot be rationally deduced that the treaties were so easily broken over a border wall. Further, per the Vienna Convention (discussed infra), for a party to withdraw or terminate treaty obligations, specific steps must be followed, including notification to other parties to the treaty. ${ }^{75}$ Thus, as will be shown, reneging obligation under the 1944 and 1970 treaties is not an easy feat.

Under U.S. treaty law, there are two kinds of treaties: self-executing treaties and non-self-executing treaties. ${ }^{76}$ Arguably, the supremacy provision in the Constitution applies to both forms of treaties. However, for this note, we need not be overly concerned with this academic debate as both the 1944 and 1970 treaties are self-executing ${ }^{77}$ and undoubtedly possess power as the "supreme law of the land." Though, when discussing treaty law, it is helpful

74 Michael P. Van Alstine, Federal Common Law in an Age of Treaties, 89 Cornell L. Rev. 892, 920 (2004) (quoting Reid v. Covert 354 U.S. 1, 18 (1957)).

75 John K. Setear, An Iterative Perspective on Treaties: A Synthesis of International Relations Theory and International Law, 37(1) HaRv. INT'L L.J. 139, 191-92 (1996) (citing Vienna Convention on the Law of Treaties art. 65(1) May 23, 2969, U.N. Doc. A/Conf. 39/17 at 289 (1969), 1155 U.N.T.S. 331).

76 For discussion of the differences between self-executing treaties and non-self-executing treaties see John T. Parry, Congress, The Supremacy Clause, and the Implementation of Treaties, 32 FoRDHAM INT'L L.J. 1209, 1329 (2009) (“[f]irst, some treaties are self-executing, which means they vest power directly in the President or are enforceable in court without legislation... [non-selfexecuting treaties] require implementing legislation to have domestic effect.").

77 See infra, for further discussion of self-executing treaties. 
to acknowledge the means used to differentiate self-executing from non-selfexecuting treaties:

[f]irst, a treaty may be held to be non-self-executing if a court finds that was the 'intent' of the treaty makers as expressed in the treaty itself [i.e. language such as 'shall be ratified and confirmed', under caselaw, indicates intent for future action] ... Second, the treaty may contemplate an obligation that constitutionally requires legislation to take effect, for example if the treaty purports to criminalize behavior or provide appropriations. Third, treaties may be incapable of or incapable of our inappropriate for judicial action... Finally, treaties have been held to be non-self-executing because they fail to provide a right of private action. $^{78}$

Applying this standard to the two relevant treaties, both the 1944 and 1970 treaties are clearly self-executing because at the beginning of both treaties, the language expressly states that two-thirds of the Senate ratified the treaty along with the President. ${ }^{79}$ There is no language of intent to act in the future to ratify the document, the documents are not vague, and there is no language indicating that legislative action must be completed for the treaty to be fulfilled. Summarily, the 1944 and 1970 treaties are self-executing. Of final note, and critical to the labeling of the two treaties as self-executing, in the context of opposing President Trump's border wall, "[a]lthough foreign affairs considerations may require respect for the reasonable interpretative views of the executive branch, the Supreme Court has declared itself the final arbiter of the meaning of self-executing treaties." 80 Thus, "[b] ecause selfexecuting treaties fall within the judicial power of Article III, federal courts... have the final authority over their interpretation and application." ${ }^{81}$ Consequently, when investigating the terms and objectives of the treaties, courts must uphold the bi-lateral treaties should the International Boundary and Water Commission fail to resolve disputes between Mexico and the United States.

Before looking into the 1944 and 1970 treaties, a discussion of treaty law would be remiss without mention of the 1969 Vienna Convention. ${ }^{82}$ The Vienna Convention represents a "formal expression of customary international

78 Huang, supra note 71, at 2229-31. (Note: Fourth prong, is likely not a correct standard, as all treaties do not confer private right of action).

79 See Treaty to Resolve Pending Boundary Differences and Maintain the Rio Grande and Colorado River as the International Boundary, U.S.-Mex., Nov. 23, 1970, 80 Stat. 271,23 U.S.T. 371; Utilization of Waters of the Colorado and Tijuana Rivers and of the Rio Grande Treaty, U.S.-Mex., Feb. 3, 1944, 59 Stat. 1219, 3 U.N.T.S. 313.

80 Van Alstine, supra note 74, at 947.

81 Id. at 946.

82 See the Vienna Convention, supra note 75. 
law anent to the obligations of States in honoring treaty obligations." 83 For members of this convention, international agreements between countries carry great weight in the international community and while the United States did not ratify the Vienna Convention, it is a signatory of the document. ${ }^{84}$ Similarly, Mexico signed, but ratified the Convention, arguably making the Vienna Convention an authority for both nations to look to when adhering to (or disregarding) treaties. ${ }^{85}$

In their article, Mumme, a Political Science Professor, and Ibáñez, a Professor of Public Administration, note that several articles of the Vienna Convention apply to the treaties between Mexico and the United States: "[f]irst, article 4 indicates that 'the Convention applies only to treaties and agreements which are concluded by States after the Convention enters into force with regard to such States." "86 Thus, while neither the 1970 Boundary Treaty nor the 1944 Water Treaty is officially sheltered by the Vienna Convention, customary international law expresses that the Convention applies to these treaties. ${ }^{87}$ However, the United States could argue that because the two treaties entered into force following signature, the Convention fails to cover either treaty. Further, the United States may reason that "the Vienna Convention limits the circumstances that justify any unilateral exclusion from the obligation of a treaty to which a State is a party." 88 Relating to the ability for the United States to avoid obligations of a treaty controlled by the Vienna Convention,

Article 62, section 1 stipulates: A fundamental change of circumstances which has occurred with regard to those existing at the time of the conclusion of the treaty, and which was not foreseen by the parties, may not be invoked as a ground for terminating or withdrawing from the treaty unless: (a) the existence of those circumstances constituted an essential basis of the consent of the parties to be bound by the treaty; and (b) the effect of the change is radically to transform the extent of obligations still to be performed under the treaty. Article 62, section 2 states: A fundamental change of circumstances may not be invoked as a ground for terminating or withdrawing from a treaty: (a) if the treaty

83 Stephen P. Mumme \& Oscar Ibáñez, U.S.-Mexico Environmental Treaty Impediments to Tactical Security Infrastructure Along the International Boundary, 49 NAT. REs. J. 801, 805 (2009).

84 Id. at 805; see also Setear, supra note 75, at 148 n.35 ("[a]lthough the United States is not a party to the Convention, the U.S. Department of State has recognized the Vienna Convention as the 'authoritative guide to current treaty law and practice."'). S. EXEC. DOC. L., 92d Cong., 1st Sess., at 1 (1971). The relevant Restatement "accepts the Vienna Convention as presumptively codifying the customary international law governing international agreements..." Restatement (Third) of Foreign Relations Law of the United States pt. III, intro. n.2 (Tentative Draft No. 6, 1985)").

85 Mumme \& Ibáñez, supra note 83, at 805.

86 Id.

$87 I d$.

88 Id. at 806; see also the Vienna Convention, supra note 75, arts. 46 \& 60. 
establishes a boundary; or (b) if the fundamental change is the result of a breach by the party invoking it either of an obligation under the treaty or of any other international obligation owed to any other party to the treaty. The combined effect of the provisions of articles 60 and 62 is to set a very high penalty and a very high bar to any party's unilateral non-compliance with treaty obligations, even when the circumstances surrounding its application may have changed. ${ }^{89}$

This section perhaps applies to both treaties and may dramatically limit the United States' ability to renege from its obligations to maintain the boundary and adhere to water allowances. Thus, the United States shall not, even for a "fundamental change of circumstance[", ignore or abandon these agreements by unilaterally building a wall that interferes with boundary delineation and water flow. Further, even if the United States claims that national security concerns undermine the international treaties' obligations, Article 46 stipulates that, "[a] State may not invoke the fact that its consent to be bound by a treaty has been expressed in violation of a provision of its internal law regarding competence to conclude treaties as invalidating its consent unless that violation was manifest and concerned a rule of its internal law of fundamental importance." 90

Here, "the United States has no basis for asserting a national security imperative for disregarding extant environmental and boundary treaty obligations to Mexico" and further, it does not appear that the United States claims "a fundamental change of circumstance with regard to any of the agreements under discussion." 91

In sum, treaties executed between Mexico and the United States, per the Vienna Convention and the Constitution of the United States, hold great weight and authority. This power cannot be easily ignored in the construction of a larger, more imposing border wall. Thus, courts must exercise great caution when balancing power between the amended IIRIRA and international treaty obligations and must soberly weigh the supposed goals of an untested border wall with the international community's trust in the United States and its respective treaty commitments.

\section{1944 Water Treaty}

The 1944 Water Treaty is an international agreement between the United States and Mexico. The treaty "allocates the waters of the two major international rivers between the two countries, stipulates the order of priorities for the use of these waters, provides for the construction of dams and other water infrastructure on the treaty rivers, and establishes a bi-national commission

89 See Mumme \& Ibáñez, supra note 83, at 806-07 (citing the Vienna Convention, supra note 75 , arts. $62.1 \& 62.2)$.

90 Id. at 806 (citing the Vienna Convention, supra note 75, art. 46).

91 Id. at 807. 
Esta revista forma parte del acervo de la Biblioteca Jurídica Virtual del Instituto de Investigaciones Jurídicas de la UNAM

comprised of two national sections to oversee the Treaty's application."92 The treaty primarily focuses on the allocation of the Rio Grande and the Colorado Rivers:

- "For the Colorado River basin, the United States is to provide Mexico annually with 1.5 million acre-feet (AF) of water.

- For the Rio Grande basin below Fort Quitman, TX: Mexico has the rights to two-thirds of the flows that feed into the Rio Grande from the six major tributaries that enter from Mexico: the Conchos, San Diego, San Rodrigo, Escondido, and Salado Rivers and the Las Vacas Arroyo (stream).

- [T] Une United States receives all flows from Rio Grande tributaries in the United States and one-third of flows from the six Mexican tributaries.

- Mexico's water delivery from these six tributaries must average at least $350,000 \mathrm{AF}$ per year, measured in five-year cycles.

- If Mexico fails to meet its minimum flow obligations for a five-year cycle because of "extraordinary drought" - a term not defined in the 1944 Water Treaty or in any minute - it must make up the deficiency during the next five-year cycle with water from the Mexican tributaries. Minute 234 established that Mexico may repay a water debt using three sources of water: (1) excess water from its tributaries; (2) a portion of its allotment from its tributaries; or (3) a transfer of its stored water in international reservoirs, such as the Falcon Dam and Amistad Dam, located on the Rio Grande on the border of Texas and Mexico."

In addition to annual water allocation, the treaty exempts water delivery given "extraordinary drought or serious accident." "94 Thus, if Mexico was unable to deliver to the United States its defined allocation, the agreement instructs how the nation may make up its water debt "at the end of one fiveyear cycle in the next five-year cycle." 95

Since the ratification of the treaty, there have been various amendments and agreements tackling issues such as "operation and maintenance of crossborder sanitation plants, water conveyance during droughts, construction of dams, and water salinity problems." 96 The Secretary of State usually adopts these amendments and agreements without Congressional or Senate action because these actions are "agreed to by the executive branch pursuant to the authority of the 1944 Water Treaty..." and "are considered binding agree-

92 Id. at 811 .

93 Nicole T. Carter Et. Al, Cong. Research Serv., R43312, U.S.-Mexican Water Sharing: Background and Recent Developments 7-8 (2017).

94 See 1944 Water Treaty, supra note 79, Art. 4(B)(c).

95 Allie Alexis Umoff, An Analysis of the 1944 U.S.-Mexico Water Treaty: Its Past, Present, and Future, 32(1) U.C. Davis L. Rev. 69, 75 (2008).

96 Carter Et. Al, supra note 93, at 6. 
ments between the United States and Mexico...."97 To illustrate, in Fall 2017, Minute 319, facing expiration, was extended and renamed Minute 323, and "requires the United States to invest millions of dollars in water conservation projects in Mexico...and allows Mexico, which has no significant reservoirs in the Colorado basin, to store some of its water north of the border. In return, the U.S. will receive a portion of the Colorado River water to which Mexico has historically been entitled."98

Minute 323 also includes agreements of water allocation, pulse flows, and investments, all geared towards water conservation. ${ }^{99}$ Because this minute is incorporated into the treaty, upon action by any U.S. president to pursue a southern border wall, should said wall interfere with this agreement, Mexico may petition the International Border and Water Commission (hereinafter IBWC).

Under the 1944 Water Treaty, the IBWC implements and enforces the agreement's terms. The IBWC “is an international body consisting of U.S. and Mexican Sections, each led by a commissioner, two principal engineers, a legal adviser, and a foreign affairs secretary." 100 The United States commission, the USIBWC, located in El Paso, Texas, "is a federal agency that operates under the foreign policy guidance of the Department of State" and whose commissioner is presidentially appointed. ${ }^{101}$ When the two nations enter into dispute, the dispute is referred to the IBWC and if the commission is unable to resolve the disagreement, "the dispute is to be settled through diplomatic channels between the United States and Mexico. Article 24 also provides that the countries may seek recourse in any 'general or special agreements which the two Governments have concluded for the settlement of controversies." 102 While this recourse has not been historically accessed, should U.S. courts continue to rely on the DHS Secretary's waiver power in finding the Secretary's actions to be constitutional, it is likely that this treaty will be infringed upon and Mexico will petition the IBWC.

The 1944 Treaty organizes the use of water into a hierarchy: first, domestic and municipal use; second, agricultural and stock-raising; third, electric power; fourth, other industrial uses; fifth, navigation; sixth, fishing and hunting; and last, any other beneficial uses, as determined by the Commission. ${ }^{103}$ Notably absent from this list is water quality. However, as the first-ranked use is for domestic and municipal purposes, a rational reading would indicate that delivered water must be fit for human consumption. Nonetheless,

97 Id. at 6-7.

98 Alastair Bland, Environment is Big Winner in U.S.-Mexico Colorado River Agreement, NewsDeeply: Water Deeply (Oct. 5, 2017), available at https://wwre.newsdeeply.com/water/articles/2017/10/05/environment-is-big-winner-in-u-s-mexico-colorado-river-agreement.

$99 \mathrm{Id}$.

100 Carter Et. Al, supra note 93, at 5.

101 Id.

102 Id. at 8 .

103 Umoff, supra note 95, at 76. 
this omission led to a long-standing dispute between the nations and greatly challenged the resolution powers of the IBWC. To illustrate, in the 1960s, the United States delivered to Mexico, water with excessive salinity levels. ${ }^{104}$ While the United States argued that Mexico should not complain about the quality of water because the nation received more water than dictated by the treaty, Mexico cited Article 3 of the 1944 Water Treaty, stating that Mexico's water purposes included domestic and agricultural use and therefore, the water delivered did not appropriately qualify under the treaty's terms. ${ }^{105}$ Following several failures in both amendments and agreements, the IBWC resolved the salinity issues in 1973 and required that the United States maintain lower salinity levels, aid in rehabilitating the damaged Mexican lands, and build additional drainage channels. ${ }^{106}$

The salinity crisis and the long-fought final solution to this water quality issue should dissuade the United States from building a wall without environmental impact studies. Because "[ $\mathrm{t}]$ he proposed wall could adversely affect three major rivers - the Rio Grande, Colorado, and Tijuana - and their tributaries that crisscross the border...", the potential long-term costs, not only to Mexico, but to the United States, could be astronomic. ${ }^{107}$ In the salinity case, because the United States ignored the water quality problem for many years, the IBWC found the nation liable for the economic losses to Mexico and responsible for building new infrastructure. Finally, prior to considering additional border wall construction, the United States should remember the long-standing, expensive salinity dispute in light of Article 17, relating to channels and international rivers states. This article states that " $[\mathrm{t}]$ he use of the channels of the international rivers for the discharge of flood or other excess waters shall be free and not subject to limitation by either country...." ${ }^{108}$ Clear from this article is the prohibition of any fence or wall built unilaterally that impairs water flow. Because the DHS Secretary is exempt from performing environmental studies, any construction absent from said study will impact relevant international treaty waters.

Prior to summarizing the legal arguments against further southern border wall construction, in light of treaty law, this note turns to the 1970 Boundary Treaty and examines this treaty in relation to the amended IIRIRA. By looking at the 1970 Boundary Treaty, in conjunction with the 1944 Water Treaty, any question left unanswered on the legality of the United States unilaterally building a border wall, absent consultation with Mexico, will be satisfied.

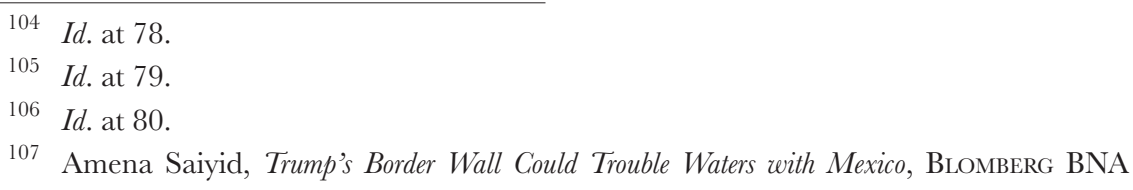
ENV. \& ENERGY ReP. (Jul. 24, 2017), available at https://wrwrbna.com/trumps-border-wall$n 73014462200 \%$.

108 Mumme \& Ibáñez, supra note 83, at 813. 


\section{1970 Boundary Treaty}

The boundary between the United States and Mexico is dynamic and flowing. It is neither a straight line, nor is it solely on dry land. Rather, per the 1970 Boundary Treaty, the border, as agreed upon by the two countries, demarcates a boundary "that falls into the Rio Grande's riverbed." 109 Per Mumme, the border is established along a "complex place geographically [and] traverse[s] through numerous ecosystems." 110 This boundary line is not conducive for a solid wall. A fact made evident by fence construction under the Bush administration, performed in direct conflict with Mexico's wishes. Consequently, the present border fence is a constant reminder to the Mexican Government that the United States failed to comply with treaty agreements. ${ }^{111}$ Here, tensions are already peaked and "[i]f the U.S. government goes for a major construction project at the border without consulting, then that would be taken as a slap in the face by the Mexican Government."112

Despite the 1970 Boundary Treaty being viewed as "one of the most important agreements between the United States and Mexico in the twentieth century," both past and present presidential administrations conveniently ignore(d) the terms of the treaty, which include qualifications on building security infrastructure along the U.S. boundary. ${ }^{113}$ For example, Article IV of the Boundary Treaty expressly "restricts the parties from unilaterally developing, without consent, any works that would impede the drainage of water to the rivers or otherwise alter the locations of the boundary that follows the center of the rivers." 114 This article further demands that, "[i]f the Commission [IBWG] should determine that any of the works constructed by one of the two Contracting States in the channel of the river or within its territory causes such adverse effects on the territory of the other Contracting State, the Government of the Contracting State that constructed the works shall remove them or modify them and, by agreement of the Commission, shall repair or compensate for the damages sustained by the other Contracting State." 115 Should Mexico assert its rights with the Commission, the United States may face large economic repercussions, be forced to remove any constructed wall found to violate the treaty, and repair all damage done as a result of the construction.

Looking back to the 1944 Water Treaty and its terms on water allocation, the building of a border fence under President Bush and the future plans to

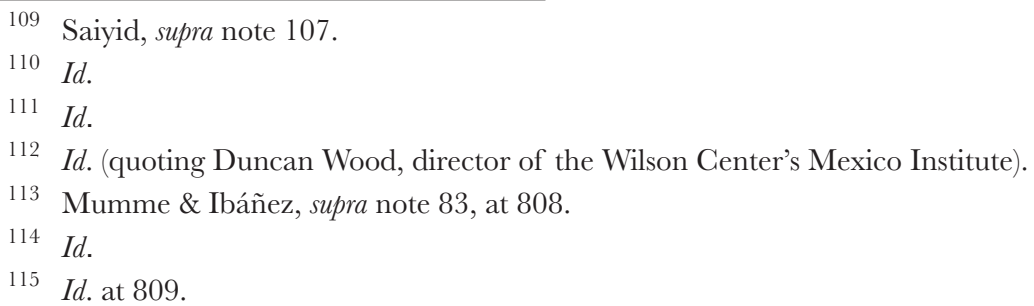


build a wall under President Trump violate, not just one, but two treaties. Notably, the 1970 Treaty allows for construction if the goal is to prevent erosion or to build channels to maintain the integrity of the "limitrophe channel." ${ }^{116}$ However, this provision is limited in scope because the IBWC must approve of the assembly and further, any construction must be done on the respective nation's own land. ${ }^{117}$ Clearly, the fence erected under President Bush failed to adhere to these requirements, for it was placed arbitrarily (where convenient), and the Commission was not consulted prior to said fence's construction. In fact, the "DHS's construction of barriers along the lower Rio Grande River as authorized by the 2006 Secure Fence Act prompted the U.S. section of the IBWC to issue a note to the DHS reminding it of these treaty obligations...."118 Unfortunately, this note was largely ignored by the DHS and due to this precedent, a reasonable forecast of the border wall proposed under President Trump is the dubiousness that future construction will respect these treaty obligations. It is clear, prior to September 11, 2001, the 1970 Boundary Treaty did not face great challenge. Nonetheless, following the terrorist attack, once the U.S. Government concluded that security necessitated a larger and longer southern border wall, the DHS illegally set aside the terms of two international treaties and currently plans to continue this trend under the Trump administration's plans for a new border wall.

\section{Discussion}

In sum, under treaty law, President Trump's proposed border wall is not legally sound. Because the 1944 Water Treaty and the 1970 Boundary Treaty are self-executing, their terms undoubtedly reign supreme per the Supremacy Clause. Under the Supremacy Clause, no state law may interfere with the treaties' terms. Second, regarding the 1944 Water Treaty, both countries are obligated to deliver to the other, a clearly defined allocation of water. Absent drought or serious accident, water must be delivered and compatible with the hierarchy of water use. This obligation is not easily altered. Per Vienna Convention Articles 60 and 62, discussed supra, a country is severely limited in what justifies a failure to adhere to treaty obligations. The United States has yet to acknowledge the probable impacts a border wall may have upon water delivery to Mexico and further, has no justifiable reason to onesidedly alter the treaty's terms through unilateral action. When combined with the newly signed Minute 323, what is clear is that relevant Mexican and American groups concerned with and most familiar with the 1944 Water Treaty's obligations, wish for the bi-lateral duties to continue and strengthen.

\footnotetext{
$116 I d$. at 808.

117 Id. at 808-09.

118 Id. at 809.
} 
Notwithstanding this evident desire, President Trump, via Executive Order 13767 and the DHS Secretary, through numerous waivers of environmental laws, equally ignore this contractual international relationship.

Along a similar vein, the 1970 Boundary Treaty established a border between the two countries that includes a 'line' running through international waters. Unfortunately, the Bush administration established precedent for encroachment of this boundary by physical construction and a fair prediction is that the Trump administration and the DHS, will likely follow suit and run afoul with the Vienna Convention. Because the 1970 Boundary Treaty terms debatably fall under the control and terms of the Vienna Convention, the Convention's restrictions apply to any thought of treaty revocation and/ or unilateral action. If the United States continues to disturb these treaties, not only will relations with Mexico sour, but the international community will hesitate to enter and trust treaty agreements with the United States. Finally, despite the IIRIRA being drafted and amended well after the 1944 Water Treaty and the 1970 Boundary Treaty were ratified and notwithstanding the language of the federal law impliedly conflicting with the treaties' obligations, the waiver of power bestowed upon the Secretary must not be interpreted as purposefully infiltrating and defeating the treaties' language. Nowhere in the IIRIRA's language, either originally written or subsequently amended, does it state that its purpose was to override the international treaties and therefore, the President cannot make such a leap to believe that, absent expressly clarifying such a break, that the IIRIRA intentionally interferes with treaty obligations.

\section{Conclusion}

In sum, following an initial examination into the IIRIRA with its expansive amendments, shadowed by a briefing of court opinions and the disconcerting track judicial opinion maintains to favor unprecedented waiver of authority, and finally, exploring treaty law and its power under the United States Constitution, it is clear is that the purpose of Executive Order 13767, to "deploy all lawful means to secure the Nation's southern border...through immediate construction of a physical wall" 119 fails against legal challenge.

First, the IIRIRA, in its present form is antagonistic to separation of powers:

[ $\mathrm{t}$ ] he waiver authority in $\S 102$ (c) is directly contrary to public policy. It delegates to a single executive official the sweeping authority to unilaterally and with unfettered discretion waive all legal requirements across up to 6000 miles of U.S. international border, potentially affecting millions of people who live in the U.S. borderlands, with no available recourse. That a single, unelected

119 Exec. Order No. 13767, supra note 8, §§ 1-2. 
official with such sweeping power could be shielded from all accountability is simply abhorrent to the idea of separation of powers, an essential part of democracy. ${ }^{120}$

Section 102, with its unfettered waiver of power, led to countless laws being ignored in the construction of President Bush's border fence under the "statutory mandate to complete the 700 miles of authorized fencing" and, more recently, under President Trump's Executive Order 13767, to construct a "contiguous, physical wall or other similarly secure, contiguous, and impassable physical barrier." 121

In addition to violating the separation of powers doctrine, caselaw illustrates other constitutional challenges lodged against Section 102, namely nondelegation doctrine intrusions, Presentment Clause violations, and impermissible judicial review limitations. However, as seen from Defenders of Wildlife, Save Our Heritage Org., and County of El Paso cases, District Courts continue to summarily dismiss these arguments. One pervading reason behind judicial hesitation to tackle the constitutionality of the broad waiver is a "foreign-affairs rationalization." 122 When the judiciary encounters laws enforced by the executive relating to foreign affairs, courts historically defer to these laws and while this deference is often appropriate, here, because the courts refuse to employ a balancing test between the objectives of the border wall and the laws infringed upon by its construction, this deference upsets the delicate balance of power among the three branches.

Last, due to the judicial tendency to uphold as constitutional the DHS Secretary's waiver power, challengers of border wall construction should look to different laws in which to supplement their arguments. Petitioners should look to treaty law and the authority treaties enjoy under both the U.S. Constitution and the Vienna Convention. Important to note, despite treaties being acknowledged as the "supreme law of the land," "the proper place for treaties in our federal system has been contested since the founding" and therefore, the tension between federal statutes and treaty obligations is still ripe for debate. ${ }^{123}$

International treaties are unique in that their authority supersedes the majority of domestic legislation and "[f] ailure to abide by these agreements could prove costly to the United States in terms of its international prestige and complicate future efforts to move forward on matters related to environmental cooperation that affect U.S. citizens at the border and in the interior as well." ${ }^{124}$ Should the United States continue to ignore the terms of the 1944 Water Treaty and the 1970 Boundary Treaty, due to rising "nationalism and

\footnotetext{
120 Neeley, supra note 3, at 165

121 Exec. Order No. 13767, supra note 8, § 3.

122 Tisler, supra note 2, at 785.

123 Huang, supra note 71, at 2216.

124 Mumme \& Ibáñez, supra note 83, at 804.
} 
indignation about the United States fence/wall project," Mexico may well assert its treaty rights and pursue judicial redress. ${ }^{125}$ Mexico will have a strong claim to counter border wall construction because the present border, per treaty terms, runs through rivers and thus, even if physically possible to build a wall in the exact outlines demarcation, the wall will drastically impact water flow and water quality. More likely, however, is that any constructed wall will not go across rivers, but, instead, will be arbitrarily located, in clear violation of the 1970 Boundary Treaty.

This nonchalance of ignoring treaty agreements reflects poorly upon the United States. Because "treaties obtain their legal force from the reciprocal international obligation of 'good faith' performance, and irrespective of their effect within the domestic law of the treaty partners,"126 the United States' Government, "for all their sovereign justification" in a post September $11^{\text {th }}$ world, "[is] not exempt from these international obligations." 127 Should the judiciary take the reins and hold the waiver power of the Secretary as contrary to treaty law, the executive branch may argue that the treaty power, as stipulated in Article II, allots them special control over treaties; however, "the inclusion of treaties in both the Supremacy Clause of Article VI and the judicial power of Article III makes clear that, where their substance so directs, the constitutional product of treaties is fundamentally the same as Article I legislation: judicially enforceable supreme federal law." 128

In close, while the United States is clearly in a different social, cultural and political conviction post-September 11, 2001, there is "little justification for exempting itself from its...treaty commitments, notwithstanding its legitimate national security interests." 129 Treaty law compels the United States to maintain its obligations to respect the border of the 1970 Boundary Treaty and continue to allow water to flow per the 1944 Water Treaty. These treaties, already threatened under President Bush's border fence will indubitably be violated to greater extent with further construction. The United States judiciary, already tested under the new administration's policies, must continue to question the President's Executive Orders and find that the waiver authority of Section 102 of amended IIRIRA is contrary to treaty laws and to the authority bestowed to them under the U.S. Constitution.

125 John Burnett, Mexico Worries That a New Border Wall will Worsen Flooding, NPR (April 25, 2017), available at http://wrere.npr.org/2017/04/25/525383494/trump-s-proposed-u-s-mexicoborder-wall-may-violate-1970-treaty.

126 Van Alstine, supra note 74, at 904.

127 Mumme \& Ibáñez, supra note 83, at 804.

128 Van Alstine, supra note 74, at 953.

129 Mumme \& Ibáñez, supra note 83, at 824.

Received: February 13th, 2018

Accepted: August 3rd, 2018. 